SECTION 12. Geology. Anthropology. Archaeology.

Hasanov Elnur Latif oglu

Ph.D. postgraduate

scholar of Ganja Branch of Azerbaijan National Academy of Sciences,

Ganja, Azerbaijan

\title{
HISTORIC-ETHNOLOGIC SIGNIFICANCE OF SOME KITCHEN CULTURE'S TRADITIONS OF GANJA CITY
}

In this scientific article for the first time have been researched the basic typical characteristics of traditions of national kitchen of Ganja. Some main local national traditions also were investigated from the historic-ethnological point of view in this work.

Keywords: Ganja, kitchen culture, ethnologic research, Azerbaijan.

Ganja city has been managed by government agencies, along with the elders. Folklore materials, collected from Ganja and historical information are confirming sayings.

Ganja kitchen with its national characteristics is differs from other regions of Azerbaijan. The cooked dishes, prepared sweets, sherbet (sweet drink) are differing for their tasty and manufacturing technology. Ganja has a positive impact on national food composition in the human body, is the health service [1]. In Ganja relationship ties are very strong. It is the tradition of Ganja people to often visit relatives, and to share their sadness and happiness. In whole Ganja's traditions are leading to spiritual pureness, they are collection of the universe laws to perfection, way of nation.

Until the middle of the twentieth century, the city was ruled by elders, elders played a role of bridge between the people and official government agencies. The most important of customs and traditions is forgiveness. During transaction people give each other forgiveness. If the patient going to die also people give him forgiveness and receive from him forgiveness. So they say: "without forgiveness will not be blessed." [3; 4].

Neighborly relations are kept and preserved strictly in Ganja. People don’t buy a house, before they interesting in neighbor's character. They say: "Don't buy house, buy neighbor; "the nearest neighbor to distant relation."

In Ganja relationship ties are very strong. It is the tradition of Ganja people to often visit relatives, and to share their sadness and happiness. "If also relative will eat each other's meat, they won't dispose each other's bone," - they said.

It is important to know that one of the areas of initially appeared human civilization was an integral part of Azerbaijan, the historical land of the city Ganja. Scientific and archaeological researches have proved that Ganja was cradle of science and culture not only of Azerbaijan, but also of the whole East.

Ganjabasar is one of the richest areas from archaeological point of view. As a result of archaeological investigations here were found samples of material culture that concerned to the stages of different history period. Today most of them are kept in various museums of the world.

The flint tools, that found in Gillikdag workshop and camp around Ganja, ladle, that were found here, give the reason to say, that people, who lived in this area in VII - VI millennium $\mathrm{BC}$ were the founders of the Late Stone Age culture.

Archaeological investigations prove that in this period the main population of this region had sedentary lifestyle and were engaged with farming. In V millennium BC in Ganja region all known to us domestic animals were domesticated. This fact is approved with osteology remainders that were found during archaeological excavations. 
The anonymous author of the article "Russian city" gave the schedule indicating the date of cities of the South Caucasus, also of Azerbaijan. And here he matched, that Ganja was founded in II century BC - IV centuries.

The same words, that match, that Ganja is older than Barda and Beylagan prove Qagemeyster's information and conception, that says " At a short distance from Barda another city was also flowering, which at the time of destruction substituted it. It was Ganja city. Their origin, probably, was the same ... ".

The majority of historical monuments, that are demonstrate the 4000 thousand year history of Ganja, which is the national wealth of our people, today gain unique place in the expositions of world's museums. In state and private museums of Metropolis, Munich, Berlin, Hamburg, Louvre, Paris, Moscow, St. Petersburg and other cities rare and valuable exhibits, that concern to the history of ancient Ganja are preserved.

Ganja city that located on an altitude of 400-450 meters above sea level is situated on the west of Azerbaijan, 375-kms to the west from the capital city Baku, on Ganja-Kazakh plain, that located in the Kura - Araz lowland, at the foot of the Lesser Caucasus on the north-east.

Most of the natural and geographical conditions, plenty water of rivers, fertile land, rich ore deposit, fuel, wood materials used for construction and craftsmanship, colored plants for getting color and natural caves allowed the first people to live in this area in the Late Stone Age.

Ganja, that has changed its location at least 4 times since its establishment, is located in a favorable position from the strategic point of view. That why it always has been the center of attention of foreigners. Ganja, that was the victim of a terrible earthquake many times, also was the subject of attacks of Mongols, Kharezms, Georgians, Arabs, Russians and other invaders. Ganja has turned to the arena of war damage of different countries of the world .But in spite of it didn't shaken, and using the genetic power revived and developed, and rose to the level of great cities. Protection of independence and state traditions by Ganja's people under Javad Khan's direction and showing an example of heroism against aggressive Tsarist Russia is forming a glorious page of our history.

In Ganja people mostly pay attention to real-generation, family. If someone wants to marriage his son or daughter, he interests with generation and family of the opposite side.

Sometimes, when families can't pliable with each other, they say: "Our bone connected with their bone." When they speak about bone, they mean father's line; about milk they mean mother's line. In this way Ganja people were able to kept and preserved pureness of generation. Ganja people are very strong in friendship. Also they can die for friend. Friend will pay all the needs of friend, will be his back-support. The equality in friendship is very important: «Show me your friend, and I will say you who you are. Ganja is famous for its hospitality. Most traditions of meeting guest are followed today.

For guest in Ganja, as a rule, separated a special room - sitting room. This room is decorated with expensive carpets, put delicate dishes, silk bedding for the guest. For breakfast of guest put cream with honey. For dinner and supper are prepared delicious foods. Among them a plov seasoning with meat and lamb meat kebab are take a special place. Ganja people put all kinds of table-blessing for guest. In addition they tell to guest kind words, and take to interesting places, worth visiting and pilgrimages. They never ask, when the guest will return.

This act shall be considered as disrespect. "The guest is God's guest ", - say Ganja people and meet the guest with honor, various gifts and send with respect. One of the more preserved customs and traditions of Ganja, that has deep historical roots, is the tradition of the wedding. Wedding, that full of rites and ceremonies is a whole holiday of elin. In this case, the close people, relatives are more active [5].

The wedding took place in stages girl for so long everyone is happy. In the past there were various games, competitions and races in Ganja weddings. Now, some of these wedding 
are traditions are forgotten. Ganja didn't have girl's wedding. Instead of it, there was "Parchakesdi" ("piece cutting”) ceremony. "Parchakesdi" was replaced girl’s wedding. And now the tradition of cutting the girl's wedding piece is also preserved. Such traditions as "khınayakhdı", "uchashi”, "evgordu” are live on nowadays. As all the parts of the world, mournful funeral ceremonies in Ganja hold very sadly. Relatives of dead man put on black clothes, don't go to parties for a while, and don't listen to music. The first day of man's dead, third day, seventh day, 40th day and "adna" days (Thursdays) funeral ceremony is continue. Ganja's funeral ceremonies can't be without rose water. Good smell of rose water eliminates man's pain. When people live funeral ceremony, they give condolences to the owner of mourning. Also, it is necessary to teach the local national holiday's traditions in Ganja. Khidir Nabi and Novruz holiday in Ganja are celebrated ceremonial. In holiday of Khidir Nabi people roast wheat, and set Khidir's table.

Then the flour of roasted wheat people put to secret room. Khidir Nabi comes at night, and put on finger to flour of roasted wheat. In house, which Khidir entered, there will be abundance.

Ganja people are going to celebrate Novruz holiday within a month. They keep in order house a, different kind of sweets are prepared. Among them Ganja's pakhlava take more attention. Pakhlava, which consists of nine layers, decorates tables. Eggs are colored; "nazik" (sweet bread) are cooked. Bearing a grudge are reconciled, people visit sick, lonely relatives. People skipped over the bonfire, goes to ear fortune telling, look fortunes in the water, visit and take holiday gifts branded girls, sick, elderly people [1-3].

Ganja pakhlava can be cooked with nuts and almond. Contents of dough: flour, egg, sour cream, rose water. As usual pakhlava contains of twelve layers. We make 2 thins, in interm we cover it with oil then on each layer we put sugar powder, nuts and add stuffing which is made of cardamom.

Then we colour our dough with liquid made of saffron. After it we cut our dough in the shape of rhombic and cover it with nuts and other things as you like. Corners we decorate with khash-khash. Bakhlava is cooked in copper trays on the coal. On the cover we use syrup (honey, sugar powder).

Irishte pakhlava is made of wheat flour and starch. With rose water liquid dough is made in round figures. As one layer Irishte is put, stuffing which is made of roasted nuts, sugar, cardamom is covered in thick form. Then irishte is put. We make it three times. Upper layer is cut in the form of rhombic. The rhombic shape is decorated on the cover of irishtebakhlava from four sides with saffron, in the middle we add clove.

Zilviya. Ingredients: flour, egg oil, yoghurt, starch. Liquid dough is made of these ingredients. Liquid dough with funnel in rounds is poured into vegetable oil. As it cooked in hot way we put dough into sugar and syrup in water. After 5 minutes the dough is extracted. As we represent the sun we use golden or red colours on liquid dough.

Nazik. Ingredients:flour, sugar, saffron, butter, milk, egg, salt, yeast and ground coriander seeds, with these ingredients dough is made. We make dough balls in the shape of bread. Then we can cover it with almond-shaped button, dehreburni, nebati, and also draw the surface of dough balls with patterns in the shape of geometric figures of national ornaments. At last we cover the surface with egg and sow with khash-khash, after that the dough is cooked in the oven.

Shekerbura. Ingredients: flour, butter, egg, milk, rose water, yeast and salt. With these ingredients dough is made. Nuts in sugar powder, nuts or almond and ground cardamom are used for stuffing. Dough is cut in small pats.On each pat we use stuffing then wrap them up. After the corners are wraped up the surface of shekerbura is decorated with tweezers. We cook shekerbura within ten minutes in hot oven. 
Kete. Ingredients: flour,butter, egg, yoghurt and aromatize things. With these ingerdients we make dough. For stuffing it can be used butter, flour, sugar powder. Adding the stuffing into the dough in the form of roll we wrap it up and with special tool for these roll we cut the dough in rhombic forms. For the surface yolk can be used. Then it is cooked inoven [2-4].

\section{Bibliography:}

1. Guliyeva N.M., Hasanov E.L. Investigation of basic decorative-applied arts of Ganja on the basis of some innovative arguments and technologies / Science and Society: Proceedings of the 3rd International scientific-practical conference. London: SCIEURO, London, (Great Britain), 2013, p. 281-291

2. Кавказский календарь на 1854 г. Тифлис, 1853, с. 338-341

3. Hasanov E.L. About fundamental studies on local cultural traditions of Ganja // European journal of Natural History (Fundamental researches: Proceedings of International scientific conference. - Jordan, Aqaba), 2013, № 3, p. 65-68

4. Azərbaycan etnoqrafiyası: 3 cilddə, I c., Bakı: Şərq-Qərb, 2007, 544 s.

5. Həsənov E.L. Gəncə İmamzadə türbəsi (tarixi - etnoqrafik tədqiqat). Bakı: Elm və təhsil, 2012, $268 \mathrm{~s}$.

6. Hasanov E.L. Some innovation historic-ethnographical arguments about development of craftsmanship in Ganja / Science, Technology and Higher education: Proceedings of the 1st International scientific - practical conference. Westwood: Publishing office Accent Graphics communications, Westwood, (Canada), 2012, p. 485-491 